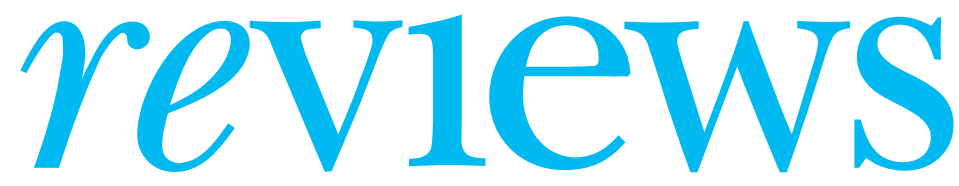

BOOKS • CD ROMS • ART •WEBSITES $\bullet$ MEDIA $\bullet$ PERSONAL VIEWS $\bullet$ SOUNDINGS

\section{The Theatre of Life and Death}

An exhibition at the Boerhaave Museum, Leiden, the Netherlands, until 21 September 2003 www.museumboerhaave.nl

Rating: $\star \star \star$

$\mathrm{H}$ aving freed itself from the Spanish empire, the Republic of the Seven United Provinces of the Netherlands was by the 17th century a superpower to rival Britain. Known primarily through its art, the Dutch Golden Age was also a period of great scientific and medical advance.

The new ideas of the Italian renaissance filtered north, driving out the medieval superstitions, including those related to health and illness. Works such as Vesalius's Atlas, new herbalist volumes, and discoveries both earthly and celestial inspired the protestant Dutch to build their own new age of research and anatomy.

It was the beginning of the end of seeing illness as God's will and the start of seeing it as something fathomable, preventable, and treatable. Humanism and the reformation had created the idea that man was on the earth to be productive; even the poorest had to work, so they had to be kept well enough to do so. "The Theatre of Life and Death" is an attempt to show how the powerful Dutch cities dealt with sickness and death as they took over the Catholic church's obligations to provide for the poor and elderly.

In 1636 the building that now houses the Boerhaave Museum, where the exhibition is on display, became the first teaching hospital this side of the Alps. Twelve beds were set aside for "interesting cases" to be poked, prodded, and discussed in Latin by medical students. Later, Herman Boerhaave developed teaching methods here that drew students from around the world, were widely copied from Philadelphia to Moscow, and remain influential today.

The exhibition is centred on a full scale copy of Leiden University's anatomy theatre, a recreated surgeon's shop, and a hospital ward of the day. Within this framework is a wide range of medicine related art and technology, from wax cadavers by Petrus Koning, natural history collections, and examples of how other fields such as astronomy and cartography were contributing to raising the level of medical knowledge.

There are icons and statues as well as oil paintings of the time, exhorting the public to honour the new medical professions, as well

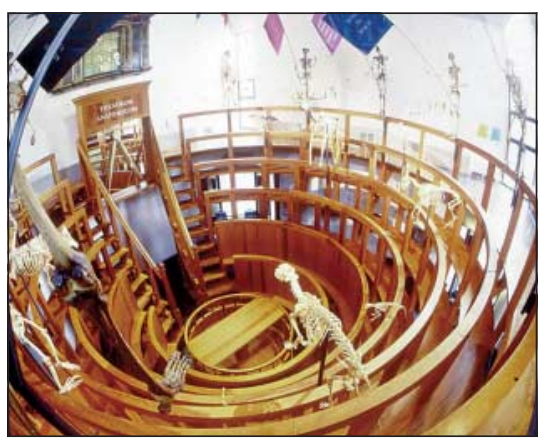

A full scale copy of Leiden University's anatomy theatre

as the regentessen or governors of the new hospitals who made the financial and appointment decisions.

The Four Guises of the Physician (Anon, 1600-1625) may ring some emotional bells with modern medics: the physician on house call is portrayed first as a messiah-like saviour, then with decreasing appreciation as the patient recovers, until by picture four (the presentation of the bill) he is depicted as the devil incarnate.

Jules Marshall freelance journalist, Amsterdam Jules@xs4all.nl

\section{Federal Bodysnatchers and the New Guinea Virus:} Tales of Parasites, People, and Politics

Robert S Desowitz

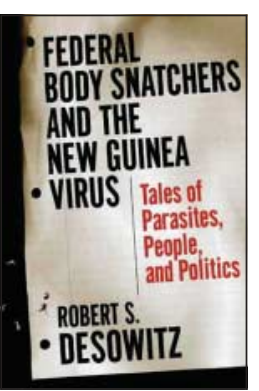

W W Norton \& Company $£ 19.95 / \$ 24.95 / \$ C 35.99$ pp 262

ISBN 0393051854 www.wwnorton.com

Rating: $\star \star$

A mong the many hopelessly wrong medical predictions that the experts have made, perhaps the most off the mark was the comment by the US surgeon general, Walter Stewart, in 1967 when he stated that "medicine was conquering infec-

Items reviewed are rated on a 4 star scale (4=excellent) tious diseases." We are well into the AIDS era and now also in the time of SARS, and clearly infectious diseases have not been conquered. Many have asked how the experts could get their forecasts so wrong. Robert Desowitz also investigates why the predictions went awry and what possible solutions there are for parasitic diseases.

Desowitz suggests that we are not equipped to handle bioterrorism. He shows how mere changes in lifestyle and global warming have led to massive outbreaks of cryptosporidiosis in Milwaukee, Hantavirus pulmonary syndrome in the Four Corners region of the United States, and the entry of the West Nile virus into Europe and America.

Federal Bodysnatchers is an interesting read and certainly Desowitz is good at explaining disease concepts. The epidemiologists and researchers, the "disease cowboys" to use a term from Laurie Garrett's book The Coming Plague (BMJ 1995;311:1378), are colourful, anti-establishment guys. Desowitz is critical of governments and organisations such as the World Health Organization ("a toopoliticized body, best at furnishing slogans"). $\mathrm{He}$ is at his acerbic best when he denounces the National Institutes of Health Office of Technology Transfer for attempts to patent a cell line resistant to cancer that had been found in a man from a remote hill tribe in Papua New Guinea in 1995 (BM) 1995;311:1452)-hence the term "federal bodysnatchers." Desowitz calls this the "index case" in the future wars on patenting of DNA/life forms. He questions the ethics, humanity, and common sense of an industry that refuses to research cures for diseases of the developing world.

Yet this book falls short of the standard set by The Coming Plague, which also showed that the bug empire was striking back with a vengeance. The weakness of this book is that it addresses too many issues from parasites to patents and thus lacks focus. It appears to have been written primarily for the layman, judging by phrases such as "inflammation of the brain and its membranous envelope (meningoencephalitis)." There are no references because "the popular book should not be cluttered with long lists of citations. Few people read or refer to them." Perhaps because of this target audience, Desowitz adopts a gung ho style of writing, which is far too casual and conversational, as the book's title and chapter titles indicate.

Sanjay A Pai consultant pathologist, Manipal Hospital, Bangalore, India

spai@bgl.vsnl.net.in 


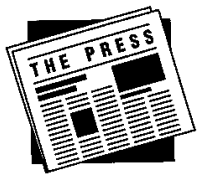

\section{MMR: more scrutiny, please}

\section{The public feels the media were too quick to report maverick claims}

$\mathrm{T}$

he media love a maverick. That's one reason why a figure such as Dr Andrew Wakefield, who challenged established thinking over the measles, mumps, and rubella (MMR) vaccine, has received so much coverage in the British press. But although some newspapers have presented Wakefield as a popular hero, fighting scientific officialdom on behalf of parents worried about autism, nearly half of the public believes that journalists should have subjected his claims to more scrutiny before reporting them.

A study of what and how people learn about science from the media discovered that $48 \%$ of the public felt that when scientists go against the grain, as Wakefield did in suggesting a link between MMR and autism, the media should wait until other studies confirm those findings before covering them. Thirty-four per cent of the survey sample of more than 1000 people thought that the media should give such scientists prominent coverage and 18\% expressed no opinion.
The public's reticence might seem "odd," particularly since MMR "does not involve issues of privacy, and since such work may already be in the public domain through publication in reputable journals," say the researchers from Cardiff University School of Journalism. "But it speaks to the degree to which many people feel the need for expert guidance on scientific issues."

The researchers analysed the way in which science and science related issues were reported on television news, radio news, and in the press during seven and a half months in 2002. They also used two nationwide surveys (using representative samples of more than 1000 people), carried out in April and October 2002, which tracked the public's knowledge, opinion, and understanding of science related issues reported in the media. The focus of their attention was on climate change, the MMR controversy, and cloning and genetic medical research.

Their report, Towards a Better Map: Science, the Public and the Media, published last month, found that what people knew usually corresponded with those aspects of a story that received most persistent coverage. "The details or subtleties of media coverage are, in this respect, much less important than the general themes of that coverage, in which certain ideas are repeated and associated with one another," says the report MMR and autism is one example of such repetition and association. "While this does mean some information is communicated effectively to most people, it can also result in widespread misunderstanding-even if the reporting itself is generally accurate."

In the case of MMR and autism, people were also misled by the journalistic quest for

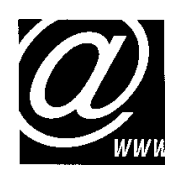

Chlamydia Trying to find quality information online about a subject such as Chlamydia is not easy-a simple search in any web based engine throws up a lot of sites, but not a lot of useful ones. Pop-ups and the tons of information from drug companies can make your web experience miserable.

But there is often some hidden oasis. In the case of Chlamydia, the subject of WEBSITE OF THE WEEK a paper in this week's BMJ (p 1252), www.chlamydiae.com is an excellent site for free. There is much here about any Chlamydia related topic, and the information has apparently been produced and peer reviewed by Chlamydia experts. This is undoubtedly the site for anyone wishing to know more about the Chlamydiae family. The site is also available in Arabic, Chinese, French, German, Italian, Japanese, Portuguese, Russian, Spanish, and Thai.

Good information about Chlamydia infection is often found on sites dealing with sexually transmitted infections in general. The World Health Organization has a page on the global prevalence and incidence of selected curable sexually transmitted infections (www.who.int/docstore/hiv/GRSTI/000.htm), which is useful for anyone trying to find data about the disease. The site provides information about Chlamydia in the most deprived regions in the world. However, the data is not that new-the most recent figures are from 1999.

Basic scientific information about the microbiology of the genitourinary

Adrian

Gonzalez

$B M J$

Clegg scholar

agonzales@

bmj.com system is available from the Graduate School of Biomedical Sciences at The University of Texas Medical Branch (http://gsbs.utmb.edu/microbook/ ch097.htm). Information suitable for patients, in an easy to read format and with good explanations, is available from Planned Parenthood (www.plannedparenthood.org/STI-SAFESEX/chlamydia.htm).

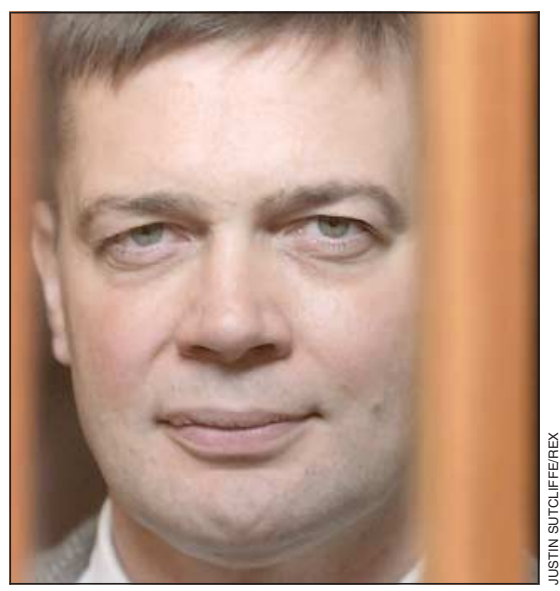

Wakefield: not "comprehensively" challenged

balance in reporting. The researchers say, "We discovered that the coverage was unintentionally misleading in creating the impression that the evidence for the link was as substantial as the evidence against it." This is a finding that also emerged in preliminary results released last September (BM) 2002;325:603). Only 30\% in the April survey and 23\% in the October survey were aware that the bulk of the evidence favoured supporters of the MMR vaccine.

The researchers found that Wakefield's claims-of a speculative link between the MMR vaccine and autism, "with questionable scientific data to support it"-were not "comprehensively or systematically challenged in media coverage." Instead, the media leapt to the speculative link, and then, because the risks of non-vaccination were fairly clear, the idea of offering three single jabs gained a great deal of currency. This put government and scientists supporting MMR on the defensive, and pitched them against the notion of parental choice. "This created a serious difficulty for the scientists and health professionals, who are only able to propose dry generalisations against the more emotive and sympathetic figures of parents concerned for the welfare of their children," says the report.

The researchers say that "while Wakefield's claims are of legitimate public interest, our report does give credence to the view that research questioning the safety of something that is widely used should be approached with caution, both by scientists publishing that research and journalists covering it." They add, "This is especially the case if any decline in public confidence has negative consequences for public health."

This does pose a difficulty for journalists, however, and for non-specialist reporters in particular: how to distinguish an MMR from a thalidomide. Sometimes, it seems, the public wants them to raise the alarm and sometimes it doesn't. And sometimes there is simply just no alarm for them to raise.

Trevor Jackson assistant editor, BMJ tjackson@bmj.com

Towards a Better Map: Science, the Public and the Media is available at www.esrc.ac.uk/esrccontent/connect indexpub.asp 
PERSONAL VIEW

\section{VOMIT (victims of modern imaging technology) - an acronym for our times}

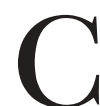
ase $1-\mathrm{A}$ request arrives for an urgent neurosurgical consultation. The urgency is reinforced by several telephone calls. A 12 year old boy with headaches has had a head scan-nowadays more likely magnetic resonance imaging (MRI) than computed tomography-that shows an arachnoid cyst. The parents have been told that the clinical diagnosis of migraine (the scan was performed "just to be on the safe side") has been changed to something more sinister. The parents are terrified, their fears not at all eased by being referred to a brain surgeon. After all, everyone knows that when doctors talk about a "cyst" they really mean cancer.

Case 2-A 15 year old girl complains of back pain. A neurological examination and various blood and radiological examinations are negative- except for the MRI scan ("I'm sure there'll

\section{The internet is the} most potent anxiety provoking system ever devised be nothing, but let's be certain"). The scan shows a mild focal dilatation of the central canal of the spinal cord over two vertebral levels in the mid-dorsal region. She is referred for a neurosurgical opinion with a presumed diagnosis of syringomyelia. Her parents surf the net. Now they know all about small muscle wasting, intractable pains, dissociated sensory loss, and the strong likelihood of progressive neurological deterioration. They also learn that a major spinal (or, worse still, craniospinal) operation is the only way to alter this gloomy prognosis. They arrive for the consultation shattered but resigned.

These hypothetical examples of "innocent pathology" are based on examples from my own specialty, paediatric neurosurgery, but I am sure that readers will have similar examples from their own disciplines. And I'm equally sure that, like me, you spend much of your time reassuring anxious patients and relatives that what some state of the art, gleamingly expensive piece of equipment has shown is no more than a red herring. And their relief that surgery is not needed may give way to resentment at how they have been "put through it" and disappointment that they may be no nearer a solution to their problem.

The history of imaging since the discovery of $x$ rays has been one of an exponential rise in the volume and accuracy of information, acquired against a background of firstly increasing and then reducing invasiveness-and rising costs. This has allowed such investigations to move tentatively from being purely symptom driven to being non-symptom driven. It is small wonder that the flood of information from these investigations and our knowledge of how to deal with it may be several years out of step.

But there is a more sinister danger. Because a medical setting and on-site medical expertise are not necessary for our new imaging techniques, the ties between the medical indications for a particular test and the motives for carrying it out are inevitably loosened. And thus the opportunity for financial gain moves into conflict with clinical need. There is no reason why imaging equipment should not be run on a commercial basis. It is perfectly natural for a commercial company, a healthcare organisation, or even a group of doctors to want their expensive equipment to pay its way and, hopefully, turn in a profit-but it's at this point that the restrictions associated with medically selected referrals can become something of an impediment. It's more cost efficient to do scans on everyone who wants oneeffectively self referral whether a doctor signs the form or not-and cut out the intermediary. Throughput and commercial survival become inextricably linked. Pack in the punters-and if any health benefits result, well, that's an agreeable spin off.

Such a policy will inevitably produce a bumper harvest of both "normal" and unanticipated "abnormal" results. But it is people with normal results, especially the anxious and credulous, who will provide rich pickings for the unscrupulous. Anxiety is the catalyst for this process, of course, particularly among people who are wealthy and gullible enough to swallow the line that the more sophisticated the investigation, the healthier they must be if their results keep coming back "normal." The internet, with its emphasis on the generality of perceived ill health over the particular needs of the individual, is of course the most potent anxiety provoking system ever devised, its influence enhanced by the democratic availability of input from both the well meaning supplier of information and the charlatan.

So where does this leave us doctors? We adapt to a world in which we must accept VOMIT as a reasonable price for our technological advances. But it's also a world in which that well tried and tested concept, the doctor-patient relationship, exists to help us translate the anxiety-provoking generality into, we hope, the reassuringly individual.

But wasn't that always our job?

Richard Hayward consultant neurosurgeon, Great Ormond Street Hospital for Children, London Haywar@gosh.nhs.uk

\section{SOUNDINGS}

\section{Young doctors, old lawyers}

When it comes to choosing a doctor, or for that matter a lawyer, age is clearly one of the determining factors. An old saying on this subject, "old lawyers and young doctors," would suggest that doctors should be young, enthusiastic, brimming with energy, but that lawyers are at their best when they are older, more seasoned, and more experienced.

Anthony Trollope addresses this subject (from the perspective of choosing a lawyer) in one his lesser known novels, Orley Farm. There he contrasts a naive young lawyer who returns from an academic meeting persuaded that the role of lawyers is to discover the truth, with one more experienced who has no time for newfangled ideas, insists that a lawyer's first duty is to his client, and wins a case even though the defendant later turns out to have been guilty.

For the healing professions, however, there is another saying: "Seek old physicians but young barbers." It presumably dates from the days when the barbers and surgeons were part of the same cutting profession, and suggests that surgeons (and barbers) deteriorate with age (or at least their hands become less steady), but that physicians improve.

Notwithstanding these arguments, a Wall Street Journal writer has opted for youth. In "How to pick a doctor" (11 November 2002) he recommended choosing a doctor just out of training, one who would have recently seen many sick patients and been exposed to the latest science, and who would also be more likely to remember you, "since you aren't the millionth patient in his [or her] career." He would have more energy than a veteran, and would be more easily available because he is just beginning to build a practice.

The writer further advises picking a doctor who also does some teaching, and finding out where he went to school, where he served his residency, and what are his views on certain controversial medical issues. The informed consumer should ask if he can see him today if he gets ill, if his office runs on time, and, in these days of instant communication, whether he can communicate with him by email.

But for the many deprived of the luxury of a choice, and for the few with an unambiguous preference for youth, the alternative is to wait in a teaching hospital outpatient clinic and have their history taken by a young medical student.

George Dunea attending physician, Cook County Hospital, Chicago, USA 